\title{
STUDY OF SOLIDIFYING MIXTURES IN MINING KRYVYI RIH IRON ORE DEPOSIT "KIROV"
}

\author{
Serhii Pysmennyi \\ Kryvyi Rih National University, \\ Ph.D. (Engineering), Associate Professor, Ukraine \\ Valerii Pozdniakov, \\ Department of Polytechnic Institute of Gamal Abdel Nasser \\ University of Conakry, Professor, Republic of Guinea \\ Victoria Biluk \\ Kryvyi Rih National University, \\ student, Ukraine
}

\begin{abstract}
The work addresses the issue of selecting a solidifying mixture when mining deposits of naturally lean iron ores by open stoping systems to decrease mining costs without the concern for surface subsidence. Magnetite quartzites are mined by systems applied to mining naturally rich iron ores that provide for leaving significant reserves in pillars. In view of the above, when mining magnetite quartzites, it is reasonable to consider application of open stoping with backfilling. Application of polymer additives in the backfill instead of cement allows decreasing costs for water and binders while retaining its strength. As they are able to couple with any binders and fillers, polymers can be added to not only concretes and cement grouts. This provides opportunities to widely use mining and concentrating wastes, i.e. slag and waste rock. Advantages of applying mixtures with plasticizers are: lower labour costs, reduced risks of cracking, increased abrasion resistance, lower shrinkage, increased resistance to temperature fluctuations, backfilling without vibrations, a longer concrete mixture lifecycle. Aggregate technical and economic indicators demonstrate that with similar physical properties of the backfill, polymer-based backfilling is 2-3 times cheaper as compared with the cement-based one. Thus, when stoping with backfilling at Artem underground mine, it is advisable to use a polymer blast furnace slag backfill as a solidifying mixture.
\end{abstract}

\section{Introduction}

The iron ore deposit of Artem underground mine (the PrJSC "Central GZK") is located between property areas of underground mines "Rodina" (the PJSC "Kryvbaszalizrudkom") in the north and "Hihant" (the PJSC "Central GZK") in the south. Below the level of $1045 \mathrm{~m}$ of Artem $\mathrm{u} / \mathrm{m}$, rich iron ores are mined by the mine group of 
the PJSC "ArcelorMittal". The underground mine's property stretches for $2.2 \mathrm{~km}$ from the southwest to the northeast [1].

Magnetite quartzites of the first and second ferruginous layers occur in the footwall of the mined-out areas of reach iron ore deposits. Geology of the deposit is made of granitoid rocks of Dniprovsko-Tokivska and Kirovohradsko-Zhytomirska series and the metamorphic complex of Kryvorizka series.

The ferruginous layers are made of martite, goethite-hematitemartite, silicate- carbonate-magnetite, silicate-magnetite and magnetite quartzites with schist bands. Thickness of the ferruginous layers varies from 4 to $100 \mathrm{~m}$. The schist bands that are $20-100 \mathrm{~m}$ thick consist of quartz-sericite-chlorite schists with ore-free quartzite interlayers.

The main ore-bearing structure of the deposit is Saksahanska syncline made of magnetite-quartzite layers and rich iron ore bodies. The latter occur mainly in the fourth, fifth and sixth ferruginous layers.

Magnetite quartzites occur in the first and second ferruginous layers in the footwall of rich iron ore bodies under mining.

The quality of ferruginous quartzites of the first and second ferruginous layers varies significantly on the strike and on the dip. Difference between the maximum and minimum iron content in $S_{x}{ }^{1 f}$ reaches $1.6-1.3 \%$ for $\mathrm{Fe}_{\text {tot }}$ and $1.68-1.23 \%$ for $\mathrm{Fe}_{\mathrm{mag}}$, in the second ferruginous layer $S x^{2 f}$ it makes $1.9-0.8 \%$ and $4.3-3.5 \%$ respectively. On the strike, these fluctuations make 1.7-1.0\% for $\mathrm{Fe}_{\text {tot }}$ and 2.5$2.0 \%$ for $\mathrm{Fe}_{\text {mag }}$ in the first ferruginous layer, and $4.1-2.9 \%$ and 4.6$2.5 \%$ respectively in the second layer. Exploration maturity of ferruginous quartzite reserves in the first and second ferruginous layers is given in Table 1.

Quartz-biotite-chlorite schists of the first, second and third schist layers and magnetite-carbonate-silicate quartzites of the first and second ferruginous layers [2] represent the country rocks.

At present, the area of the deposit is built up with residential structures and industrial facilities. In addition, there are caving zones resulted from mining rich iron ore deposits by the above-mentioned mining companies. Along the strike of the deposit, there is a railway 
of "Ukrzaliznytsia" and a highway connecting residential areas.

Table 1

Reserves and mass fraction of iron in magnetite quartzites

\begin{tabular}{|c|c|c|c|c|c|c|c|}
\hline \multirow{3}{*}{$\begin{array}{c}\text { Cut-off } \\
\text { grade of } \\
\mathrm{Fe}, \%\end{array}$} & \multirow{3}{*}{$\begin{array}{l}\text { Stratigra } \\
\text { phic } \\
\text { index }\end{array}$} & \multirow{2}{*}{\multicolumn{2}{|c|}{$\begin{array}{l}\text { Quartzite reserves } \\
\text { by categories, kt }\end{array}$}} & \multicolumn{4}{|c|}{ Mass fraction of iron, $\%$} \\
\hline & & & & \multicolumn{2}{|c|}{$C_{1}$} & \multicolumn{2}{|c|}{$C_{2}$} \\
\hline & & $C_{1}$ & $C_{2}$ & tot & mag & tot & mag \\
\hline \multirow{3}{*}{20} & $S_{x}^{1 f}$ & 341284 & 62543 & 33.2 & 24.8 & 32.6 & 24.4 \\
\hline & $S_{x}^{22 f}$ & 218140 & 52335 & 32.8 & 25.8 & 31.8 & 25.3 \\
\hline & Total & 559424 & 114878 & 33.0 & 25.2 & 32.2 & 24.8 \\
\hline \multirow{3}{*}{16} & $S_{x}{ }^{1 f}$ & 505760 & 82339 & 32.2 & 22.2 & 32.0 & 22.2 \\
\hline & $S_{x}^{2 f}$ & 241607 & 55189 & 32.5 & 24.5 & 31.8 & 24.9 \\
\hline & Total & 747367 & 137528 & 32.3 & 22.9 & 31.9 & 23.3 \\
\hline \multirow{3}{*}{10} & $S_{x}^{1 f}$ & 617895 & 103782 & 31.2 & 20.0 & 31.0 & 19.6 \\
\hline & $S_{x}^{2 f}$ & 294966 & 65656 & 31.6 & 21.7 & 29.9 & 20.5 \\
\hline & Total & 912861 & 169438 & 31.3 & 20.5 & 30.6 & 19.9 \\
\hline
\end{tabular}

Thus, there are two options for mining magnetite quartzites of the deposits: by the open stoping method within the range of depths and by the system with complete backfilling.

When mining magnetite quartzites, there occur stopes of about $1.2 \mathrm{M} \mathrm{m}^{3}$ annually. However, when applying systems with backfilling, voids are filled with solidifying mixtures to prevent surface subsidence.

When mining quartzites by the room-and-pillar method, despite available underground voids, there is no significant surface subsidence due to pillars left [3].

Both options provide for steps to prevent development of displacement. Thus, new aquiferous areas are not entrained to the displacement zone. Due to very low filtration parameters of both magnetite quartzites and country rocks, sizes of a depression crater caused by dewatering of naturally rich iron ores do not practically grow.

To calculate reserves of the I and II ferruginous layers within the "Kirov" leasehold, two options of mining magnetite quartzites are suggested: 1) mining the underground mine field leaving pillars and 2) mining the underground mine field by the systems with backfilling. By the considered options and with the cut-off grade change from $20 \%$ to $10 \%$, proved reserves increase from 73723 to $116586 \mathrm{kt}$ and from 228453 to $361248 \mathrm{kt}$ respectively. 
Application of open stoping systems (option 1) inevitably results in 2.0-2.5-fold decrease of the reserves to be mined and requires additional monitoring of the pillar state after mining main reserves and, consequently, keeping main and ventilation shafts, mail haulage levels in the working order. The mining system with backfilling using the solidifying backfill enables mining the reserves of the deposit more completely [4].

The system of mining with backfilling prevents creation of caving craters and partly obviates the necessity of monitoring the state of the mined-out space. In view of the above, further studies of mining magnetite quartzites should focus on the second option, i.e. the mining system with backfilling.

At present, at mining rich ores, the annual progress of mining operations does not exceed 17-19 m. A low rate of deepening is conditioned by hoisting capabilities of main shafts and significant mining depth of $1200-1300 \mathrm{~m}$. The maximum annual progress at underground mining of ferruginous layers with backfilling is $17.5 \mathrm{~m}$ when traditional processes are applied [5].

From the practice of Zaporizhzhia iron ore basin (ZZRK) where self-propelled equipment is applied, the minimum annual progress of mining with backfilling makes $11.9 \mathrm{~m}$ with annual output of $3000 \mathrm{kt}$. According to the process design standards, the maximum progress makes $17.5 \mathrm{~m}$.

The underground mine applies the open stoping system with solidifying backfilling and rhomboid stopes, Fig. 1.

Within a mining site, two stopes may be worked out simultaneously in the way that between them there is a $30 \mathrm{~m}$ wide ore or backfill pillar.

The backfill is prepared at a specialized facility on the surface. It is transported to backfill levels by pipes in two holes drilled from the backfill facility. The facility comprises sand, slag and cement storage areas and a building for slag mills and mixers. The designed annual output of the backfill facility is $1.5 \mathrm{M} \mathrm{m}^{3}$ of the backfill mixture.

The following technical and economic indicators by mining systems with various shapes of stopes to be backfilled were obtained in mining the deposit, Table 2.

Analysis of underground mining operations enables the conclusion that open stoping systems and those with backfilling are 
widely used in reserve extraction [7-9].

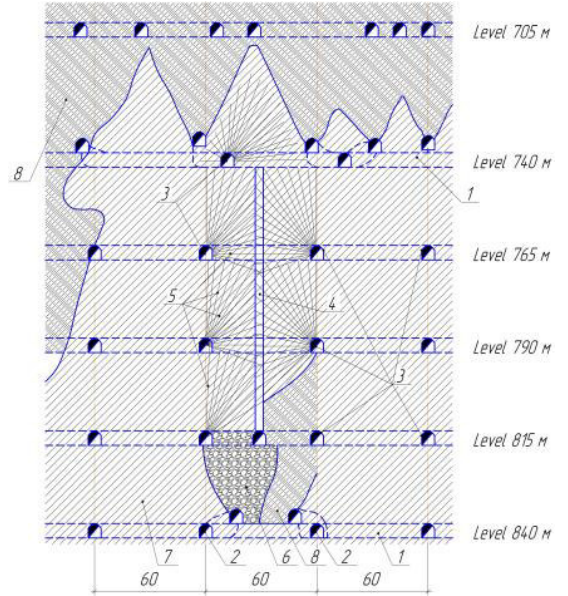

Fig. 1. Open stoping with solidifying backfill of rhomboid stopes (ZZRK):

1 - haulage drift; 2 - loading ort; 3 - drill drift; 4 - ore raise; 5 - blasthole rings;

6 - broken ore; 7 - ore massif; 8 - solidifying backfill

Table 2

Technical and economic indicators

\begin{tabular}{c|c|c}
\hline \multirow{2}{*}{ Indicators } & \multicolumn{2}{|c}{ Stope shape } \\
\cline { 2 - 3 } & Rectangular & Rhomboid \\
\hline U/m output, $\mathrm{t} / \mathrm{shift}$ & 9.6 & 11.6 \\
\hline Costs for preparatory development operations, $\mathrm{m} / \mathrm{kt}$ & $3-9$ & $4-7$ \\
\hline Broken ore losses, \% & 9.0 & 8.2 \\
\hline Ore dilution, \% & 5.6 & 4.0 \\
\hline $1 \mathrm{~m}^{3}$ of backfill cost, USD & $65-82$ & $65-82$ \\
\hline Production costs (free at joker chute), USD/t & $68-77$ & $65-71$ \\
\hline
\end{tabular}

Methods. Backfilling technologies and the composition of solidifying backfill are studied by famous scholars, M.N. Tsyhalov, M.I. Ahoshkov, O.N. Baikonur, R.M. Bronnikov, V.V. Kulykov, K.V. Miasnykov, E.O. Shternbek, V.P. Kravchenko, A.M. Kuzmenko, H.T. Faustov, Z.R. Malanchuk, V.H. Perepelytsia, S.A. Kurnosov, K.Yu. Repp, N.F. Zamesov, A.L. Trebukov, V.P. Voloshchenko, V.I. Liashenko, Ye.P. Chystiakov being among them.

Processability (strength, transportability) and cost-effectiveness (component costs, transportation costs) are key criteria for selecting solidifying backfill. Backfilling practices show direct dependence of 
backfill massif strength on binder consumption.

Scholars' contribution to increase of efficiency of mining ore deposits applying systems with backfilling focuses on issues of complete reserve extraction and development of cement-free backfill mixtures made of local materials to decrease backfilling costs.

Considerable amounts of ferrous and non-ferrous metallurgy slag in waste dumps that contaminate the environment can now be used as binders. This decreases consumption of expensive portlandcement, cement, enables even refusal of using them and provides disposal of wastes underground $[14,15]$.

Economic efficiency of using wastes of mining and beneficiation plants (GZK) as backfill with added polyhexamethyleneguanidine compounds is considered in [15] where reliability of the suggested backfill composition is also substantiated.

[16] substantiates deformation characteristics of the backfilling material with polymer fiber compounds. Tests of this material show promising results - application of polymer fibers increases shearing strength of concrete, thus suggesting an alternative method of designing joints between concrete and grout structure members.

The authors note that traditional mixtures used for backfilling underground voids possess great deformability and low strength that ultimately condition displacement of rock massifs after void elimination. Thus, it is expedient to use mixtures with reinforcing elements, e.g. disperse fiber of steel or polypropylene, for backfilling (or for moth-balling).

In addition, multiple researches demonstrate that PPV in the amount of $0.1 \%$ of the total volume provides residual strength, antimicrobic effects, reduced permeability as well as resistance to subsidence, concrete segregation, concrete cracking at plastic shrinkage, abrasion, freezing/thawing cycles, impacts and fire. This means that PPV can be used in all fields of concrete and grout application. Grouts with PPV demonstrate better adhesion that accelerates backfilling. A large content of longer fibrillated fibers can equate mixture strength to concrete with $25-30 \mathrm{~kg}$ of reinforcing steel.

To sum up the above said, it should be noted that the application area for the mentioned materials is almost limitless and will be growing in the future.

Research tasks. Thus, study and substantiation of the open 
toping system in underground mining of magnetite quartzites with further alternative backfilling at Artem underground mine (the PrJSC "Central GZK") are topical.

\section{Material and results of research}

To test the reserves of magnetite quartzite in the mine field "Kirova" it is expedient to apply a surface-chamber system of development with a bookmark of the made space. When working on the floor of $220-130 \mathrm{~m}$, it is proposed to form a vaulted chamber in the upper part [10].

The essence of the proposed option is as follows. The deposit is divided into chambers of the first and second turns of $30 \mathrm{~m}$ with a floor height of $90 \mathrm{~m}$ (Fig. 2-4).

In the lower part of the block, a trench cut is formed by drilling the ore mass with rod holes from the cutting horn. Next, form a vertical compensation chamber by drilling the ascending and descending fans of deep wells. Then destroy the array of deep wells from the drilling rig, see Fig. 2-4.

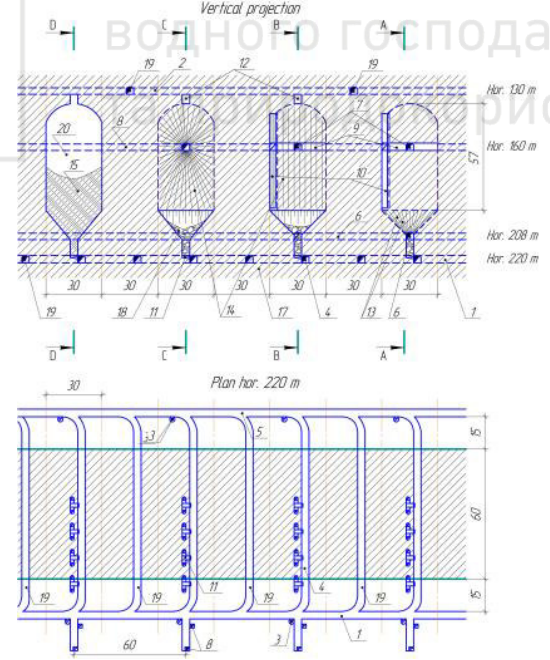

Fig. 2. Surface-chamber system of development with a bookmark of the made space at working off of stocks of mine field "Kirova": 1 - retractable drift;

2 - mortgage road; 3 - ventilating running gezenk; 4 - ort arrival; 5 - ventilated subfloor drift; 6 - cutting ort; 7 - drilling rig; 8 - material gezenk; 9 - cutting lane;

10 - detachable gezenk; 11 - paired vibrating feeder; 2 - mortgage ort; 13 - rod holes; 14 - deep wells; 15 - hardening bookmark; 16 - vertical compensation chamber; 17 - ore massif; 18 - collapsed ore; 19 - ventilation ort; 20 - mortgage chamber 
After loading and blasting of deep wells the release of collapsed ore from the treatment chamber is performed.

Production and delivery of ore is carried out by means of paired vibrating feeders.

After the complete release of ore, the cleaning chamber is filled with a hardening tab, which is transported to the chambers along the embankment road.

Having worked out the chambers of the first turn of a floor of 220-130 m begin excavation of chambers of the second turn (interchamber pillars of chambers of the first turn)
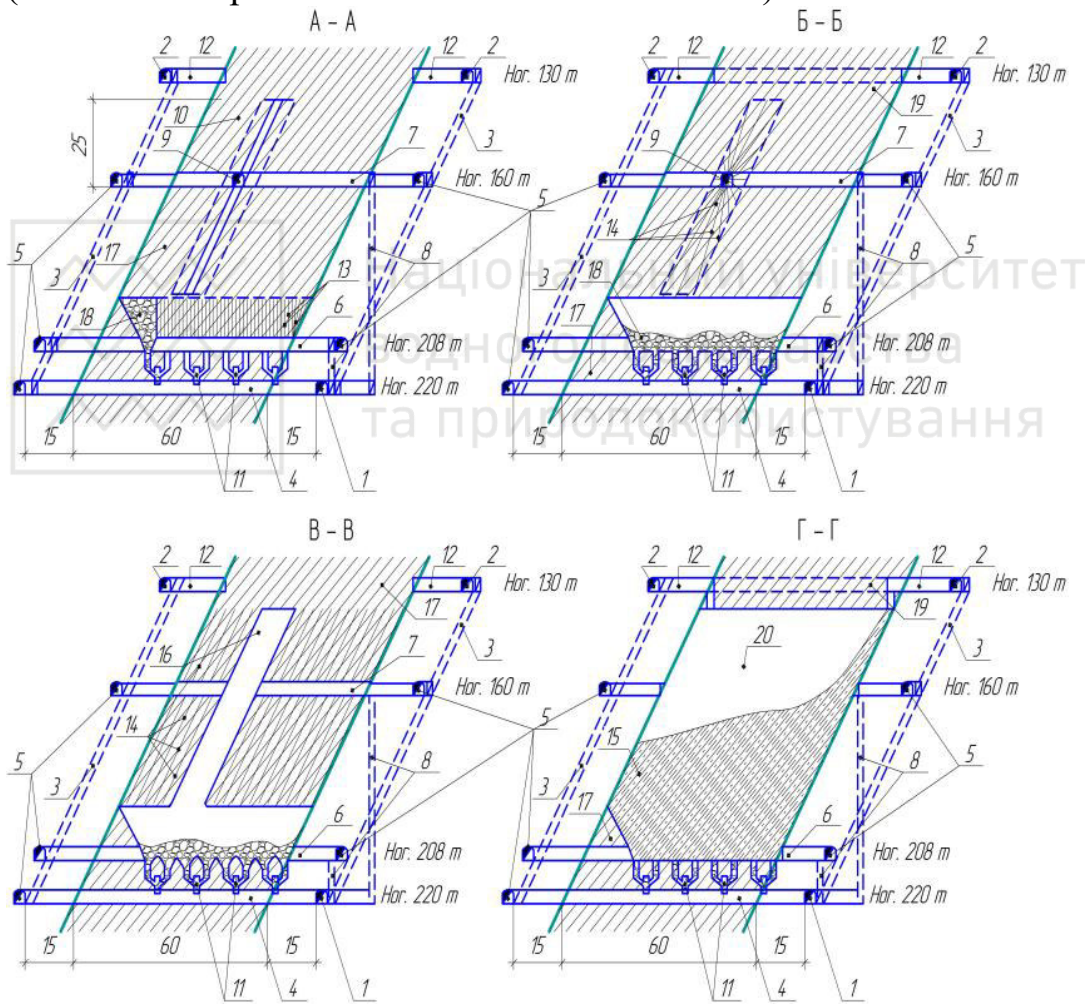

Fig. 3. Sections of the surface-chamber development system:

1-20 - symbols are shown in Fig.2 


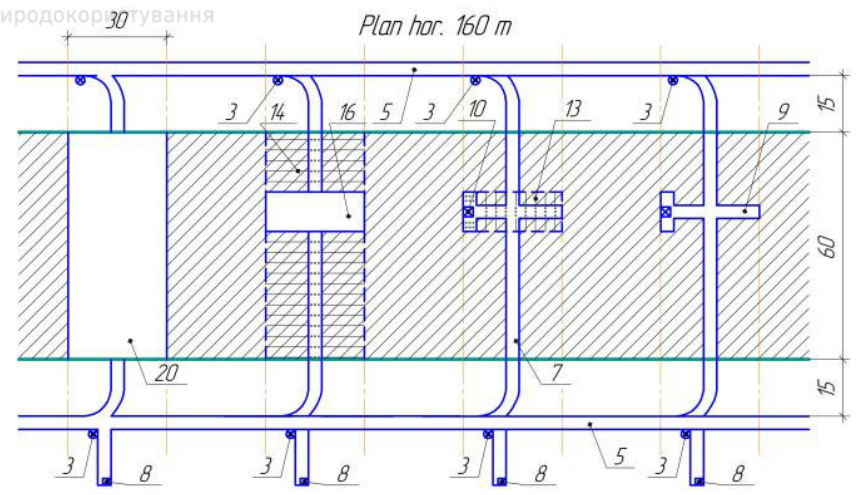

Fig.4. Plan of the surface-chamber development system:

1-20 - symbols are shown in Fig.2

It is also possible to use powerful self-propelled equipment. From the analysis of field development, loading and delivery machines are widely used.

In the laboratory of Kryvyi Rih National University were conducted studies on the stability of cameras of various shapes [11].

The results of the studies are shown in table 3.

Table 3

The results of laboratory tests

\begin{tabular}{|c|c|c|c|}
\hline \multirow[t]{2}{*}{ Name of indicators } & \multicolumn{3}{|c|}{$\begin{array}{l}\text { The shape of the cleaning } \\
\text { chamber }\end{array}$} \\
\hline & \multicolumn{2}{|c|}{ rectangular } & \multirow[t]{2}{*}{ vault } \\
\hline Parameters of the cleaning chamber, $\mathrm{m}$ : & & & \\
\hline - height & 90 & 90 & 90 \\
\hline - length & 30 & 30 & 30 \\
\hline - width & 60 & 60 & 60 \\
\hline Width of the interchamber whole, $\mathrm{m}$ & 30 & 30 & 30 \\
\hline The ultimate strength of the whole, $\mathrm{MPa}$ & 125 & 125 & 125 \\
\hline \multicolumn{4}{|l|}{ Camera behavior, months: } \\
\hline - before chipping the whole & 6 & 10 & 8 \\
\hline - chaotic chipping of the whole & 1.5 & 0.5 & - \\
\hline - intensive chipping of the whole & 9.0 & - & - \\
\hline - complete destruction & + & - & - \\
\hline Strength of the whole in 28 days., $\mathrm{MPa}$ & 30 & 105 & 118 \\
\hline
\end{tabular}

As a result of research it is established that at working off of stocks of magnetite quartzites in a floor of mountains. 130-220 m are the most stable vaulted chambers $[12,13]$. 
The principal difference of the solidifying backfill from the dry and hydraulic ones consists in its ability to not only keep its shape and properties but also withstand various loads. These features of solidifying backfill have enabled enhancement of current stoping methods and facilitated development of new ones. This type of backfillis used to create monolithic sill pillars, enclosure retaining walls, stoppings, concrete blocks. The mining industry started to apply solidifying backfills 50-60 years ago. In fact, they are a subtype of "lean" concretes that have been studied and used for hundreds of years. Due to high costs of solidifying materials, this type of backfill is used after a feasibility study into its application.

At depths of over $600 \mathrm{~m}$, consumption of binders makes $300 \mathrm{~kg} / \mathrm{m}^{3}$ and more, this necessitating the search for more economical ways of enhancing strength of the backfilled massif.

Application of expensive materials stimulates the search for alternative components of the backfill and results in the idea of introducing cheaper and more modern materials to the backfill mixture. Such additives can enhance mixture properties, this not making such mixtures inferior to traditional compositions in quality.

Polymers can be added not only to concretes and cement grouts as they can be well-coupled with any binders and fillers. They enable mixtures with the required fluidity for easier backfilling and better quality of works, give a good showing at various temperature modes (frost-resisting additives) and solidify faster with a rise in temperature. While solidifying, grouts with polymer additives become $20-25 \%$ stronger, more plastic, require less water (by 20\%) and binders (by 15\%) and do not lose their quality.

To strengthen cohesion of components in the grout, a polypropylene fiber is used as a reinforcing additive $(0.6-0.9 \%$ per 1 $\mathrm{m}^{3}$ ). This enhances adhesion of the concrete grout preventing sedimentation of large and heavy particles at compaction, thus providing plasticity of the fiber mixture in a liquid form and easy pumping.

Increased plasticity after adding the fluid-plastic polypropylene fiber prevents ruptures and segregation of cement products while receiving them from the concrete mixture or the cement grout.

Advantages of mixtures with plasticizers are: economy of 
cement; reduced efforts for receiving a smooth surface; reduced risks of concrete cracking; increased abrasion resistance; increased adhesion with the reinforcement cage (if available); lower shrinkage; increased resistance to temperature fluctuations; backfilling without vibrations; a longer concrete mixture lifecycle (up to 2 hours), degreased risks of segergation and early solidification.

Advantages of applying fiber are: decreased cracking; increased resistance to breaking and shrinkage; decreased segregation (peeling); decreased deterioration.

To enhance strength characteristics of mixtures currently used for backfilling, it is suggested to add polymers as plasticizers (e.g. CП1BП) and reinforcing polypropylene fibers to grout compositions, Table 4.

\begin{tabular}{|c|c|c|c|c|c|c|c|c|c|c|c|}
\hline $\begin{array}{l}\bar{Z} \\
\bar{U} \\
\bar{U} \\
\tilde{E}\end{array}$ & 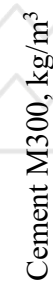 & 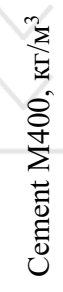 & 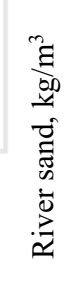 & 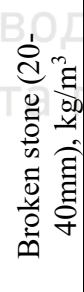 & 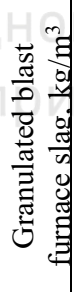 & 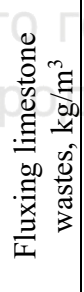 & 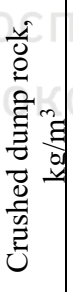 & 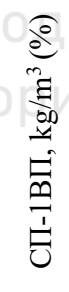 & 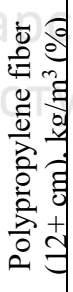 & 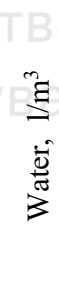 & 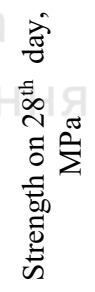 \\
\hline \multirow[b]{2}{*}{ №1 } & 300 & - & 1400 & - & - & - & - & - & - & 410 & \multirow[b]{2}{*}{$3-4$} \\
\hline & 255 & - & 1400 & - & - & - & - & $\begin{array}{l}1.35 \\
(0.6)\end{array}$ & - & 328 & \\
\hline \multirow[b]{2}{*}{ №2 } & - & 382 & 705 & 1080 & - & - & - & - & - & 220 & \multirow[b]{2}{*}{$30-32$} \\
\hline & - & 324 & 705 & 1080 & - & - & - & $\begin{array}{c}1.94 \\
(0.6)\end{array}$ & - & 176 & \\
\hline \multirow[b]{2}{*}{ №3 } & - & - & - & - & 400 & 1050 & 362 & - & - & 400 & \multirow[b]{2}{*}{$6-7$} \\
\hline & - & - & - & - & 360 & 50 & 362 & $\begin{array}{l}2.16 \\
(0.6)\end{array}$ & 0,6 & 320 & \\
\hline
\end{tabular}

It should be noted that selection of a backfill is greatly influenced by its cost. Adding polymers to the backfill composition is not always profitable, but sometimes such backfilled massifs cost less and possess enhanced properties (Figure 5). 
a)

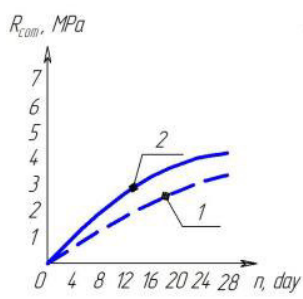

b)

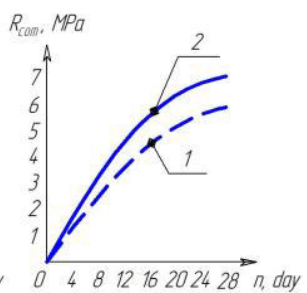

c)

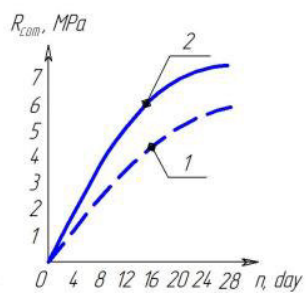

Fig. . Sample strength development in the allotted time: $a$ - bookmark based on cement M300; $b$ - bookmark based on cement M400; $c$ - bookmark based on blast furnace slag; 1 - without the addition of polymers; 2 - on the addition of polymers

When expensive mining systems with backfilling are applied, costs for materials can be reduced through optimal selection of the mixture composition considering all requirements to a backfilled massif. Application of expensive materials will no doubt enable higher quality of grouts (normal heavy concretes) and more accurate forecast of their future behaviour.

Based on the above, strength development of samples in the allotted time can be depicted. It is reasonable to use these materials only if certain properties of mixes are required. Table 5 presents technical and economic calculations for substantiating reasonability of applying the given systems and comparing various options with different backfill compositions and shapes of stopes.

Table 5

Technical and economic indicators by stope shapes

\begin{tabular}{l|c|c}
\hline \multirow{2}{*}{ Indicators } & \multicolumn{2}{c}{ Stope shape } \\
\cline { 2 - 3 } & Rectangular & Vault \\
\hline Ore reserves in block, kt & 525.0 & 450.0 \\
\hline $\begin{array}{l}\text { Specific costs for preparatory development } \\
\text { operations, m/kt }\end{array}$ & 4.7 & 3.9 \\
\hline Specific consumption of explosives. kg/t & 0.28 & 0.28 \\
\hline Labour efficiency. t/shift: & & \\
\hline$a)$ at drilling & 1228.0 & 1296.0 \\
\hline$b)$ at hauling & 1025.0 & 1025.0 \\
\hline$c)$ by mining system & 195.0 & 223.0 \\
\hline Average monthly block output. kt & 14.6 & 16.7 \\
\hline $\begin{array}{l}\text { Time for preparatory development operations. } \\
\text { months }\end{array}$ & 5 & 4 \\
\hline Time for block mining. months & 12 & 11 \\
\hline Femag content. \%: & 25.16 & 25.16 \\
\hline$a$ ) in massif & \multicolumn{2}{|l}{} \\
\hline
\end{tabular}




\begin{tabular}{l|c|c}
\hline$b)$ in mined ore mass & 24.47 & 24.51 \\
\hline Ore losses. \% & 9.0 & 8.5 \\
\hline Ore dilution. \% & 5.0 & 4.7 \\
\hline Ultimate compressive strength. MPa & $3-7$ & $3-7$ \\
\hline Backfilling costs. by composition. UAH/t: & & \\
\hline -№1 (Cement M300) & 140.7 & 164.1 \\
\hline -№2 (Cement M400) & 273.1 & 318.6 \\
\hline -№3 (Blast furnace slag) & 64.4 & 75.1 \\
\hline -№1 $a$ (Cement M300) & 136.6 & 159.4 \\
\hline -№2 $a$ (Cement M400) & 196.7 & 229.5 \\
\hline -№3 $a$ (Blast furnace slag) & 64.0 & 74.7 \\
\hline
\end{tabular}

Analysis of the data in Table 5 shows that reserves of the rectangular stope are larger by $75 \mathrm{kt}$ and difference in output by systems makes $2.1 \mathrm{kt} /$ month. ore losses and dilution differ by $0.5 \%$ and $0.3 \%$. Fe $\mathrm{Fag}_{\text {mag }}$ content is lower by $0.04 \%$.

Thus. difference in costs for mining $1 \mathrm{t}$ of ore with application of the cement M300-based backfill in stopes of different shapes varies within 4.1-4.7 UAH/t. with application of the cement M400-based backfill - within 76.4-89.1 UAH/t. with application of the backfill based on blast furnace slag the cost is $0.4 \mathrm{UAH} / \mathrm{t}$.

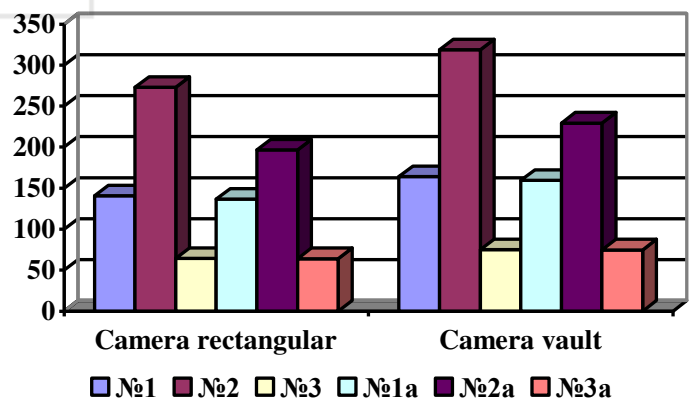

Fig. 6. Costs of mining $1 \mathrm{t}$ of ore with backfill of various composition in stopes of different shapes

\section{Conclusions}

The research conducted enables the following conclusions:

1. When mining magnetite quartzites. it is reasonable to apply the open stoping method with backfilling that prevents the surface from deformations and caving craters. 
2. Analysis of available solidifying mixtures shows that backfills based on the cement grout possesses several disadvantages (high costs and special transportation conditions). However. polymerbased backfills do not require special conditions for transportation.

3. Aggregate technical and economic indicators demonstrate that with similar physical properties of the backfill. polymer-based backfilling is 2-3 times cheaper as compared with the cement-based one.

Thus. when stoping with backfilling at Artem underground mine. it is advisable to use a blast furnace slag backfill as a solidifying mixture.

\section{References}

1. Feasibility study of production value and substantiation of condition parameters for calculation of reserves of I and II iron layers in the mining allotment of SE "Kirov Mine". - Kryvyi Rih: Kryvbasproekt, 2005.

2. Stupnik M.I, Pysmennyi S.V. Parameters of floor-chamber excavation of ferruginous quartzites with inclined pillars // Mining Bulletin: Scientific and Technical Collection. - Kryvyi Rig. - 2013. - № 96. - P. 3-7.

3. Malanchuk Z.R., Stupnik M.I., Fedko M.B., Pysmennyi S.V., Kolosov V.O., Kurnosov S.A. Investigation of the stability of the outcrops of the chamber systems of development during the development of complex structural deposits of iron ores of the Kryvyi Rih basin // Bulletin of NUVGP: Series "Technical Sciences", 2018. - Issue 3 (83). - P. 162-175.

4. Pysmennyi S.V. Investigations of the stability of the pillars from the shape of the cleaning chamber during the development of magnetite quartzites in the fields of existing mines underground // Bulletin of Kryvyi Rih National University. - 2014. № 36. - P. 9-13.

51. Pysmennyi S.V. Development of complex-structural deposits of rich ores by chamber development systems // Mining Bulletin: Scientific and Technical Collection. - 2014. - № 97. - P. 3-7.

6. Stupnik N.I., Kalinichenko V.A., Kolosov V.A., Pysmennyi S.V. Modeling of the cleaning chamber in unstable ores during the development of ore deposits / // Metallurgical and mining industry. - 2014.- No. 4. - P. 68-71.

7. Egorochkin A.A., Ezhenov A.E. Improving the technology of ore mining with backfilling during the development of steeply dipping ore bodies in difficult mining and geological conditions // Improving the technical level of mining: Proceedings of VNIItsvetmet. Ust-Kamenogorsk, 1988 .- P. 109-122.

8. Pysmennyi S.V., Khivrenko V.O., Sbitnev V.A., Polukhina N.V. Determination of the parameters of the vaulted compensation chamber // 
Development of ore deposits. - Kryvyi Rih: KTU. - 2002. - Issue. 79 .- P. 48-52.

9. Tsarikovsky V.V. Tsarikovskiy V.V., Sakovich V.V., Nedzvetskiy A.V., etc. // Determination and control of the permissible dimensions of structural elements of development systems at the mines of Kryvbass. - Kryvyi Rih: NIGRI, 1987. - 76.

10. Stupnik N.I., Kolosov V.A., Pysmennyi S.V., Fedko M.B. Development of naturally poor ores of the Krivoy Rog iron ore basin with the backfill of the workedout space / // Metallurgical and mining industry. - 2014. - No. 3. - P. 95-98.

11. Development of technology for the production of folding structured pads, which contact with overly clayey rocks: Sound about / NDR №. 30-79-09 (Conclusions) No. DR 0109U002336 // Kryvory Technical University - Kryvyi Rih, 2010 .

12. Stupnik N.I., Pysmennyi S.V. Physical modeling of the form of compensation chambers when mining blocks at great depths // Bulletin of the Kryvorizkiy National University. - 2012. - No. 31. - P. 3-7.

13. Pysmennyi S.V. Methods of assigning an active zone and a crypt on the contour of an underground transport vyrobka when combining the development of gold ore genera // Bulletin of the National Technical University "KhPI". Collection of Science Works. Series: Mechanical and technological systems and complexes. Kh .: NTU "KhPI", 2017. - No. 16 (1238). - P. 99-106.

14. Kuzmenko A.M. Petlyovany M.V., Mustache V.Yu. Solid bookmark during the release of steep ore loads at the folding geological-geological minds // Monograph: Ministry of Education and Science of Ukraine, Nat. girn. un-t. - D .: NSU, 2015. - 139.

15. Gorbunova O.A. Development of warehouses solid bookmarks on the basis of the approaches to the garnishing-zbagachuvalny virobniztva from the additional polymers of the class polyhexamethyleneguanidin // GIAB - 2010.

16. Stradanchenko S.G., Shubin A.A. On the use of cement-based fiber mortar polymer / Science Pratsi DonNTU. Series "Girnicho-geological" No. 7 (135). 2008. - P. 36-39.

17. Vasil'ev V.V. Polymeric compositions in the reference book. -M.: Nauka, 1986. - 294.

18. Kuzmenko A.M., Petlyovany M.V. The standpoint of the prospects for the development of mortgages in the underground mines of Ukraine // Geotechnical mechanics. - 2013. - VIP. 110. - P. 90-98. 